\title{
Prevalence of Listeria monocytogenes in poultry meat
}

\author{
Mehmet ELMALI ${ }^{1}$, Hayriye Yeşim CAN ${ }^{1 \star}$, Hilmi YAMAN ${ }^{2}$
}

\begin{abstract}
The objectives of this study were: i) to isolate Listeria spp. and Listeria monocytogenes in broiler wing meat samples, ii) to confirm the isolates by PCR, based on prs and hly A gene sequences, iii) to determine the seasonal and monthly distribution of the isolates. A total of 120 broiler wing meat samples (60 packaged pieces wrapped using strech film in styrofoam plates and 60 unpackaged pieces) bought from different markets in Hatay province were analysed. Listeria spp. was isolated from 57 (47.5\%) out of 120 samples. Fifty-four, out of 57 Listeria spp. isolates were identified as L. monocytogenes. L. monocytogenes was isolated from the samples collected during the spring, winter, summer, and autumn at the levels of $26.6 \%, 40 \%, 53.3 \%, 60 \%$, respectively. In this study, the isolation rates were found to be the highest in autumn, while the isolation rates were found to be the lowest in spring. As a consequence, high prevalence of Listeria spp. and L. monocytogenes in poultry wing meat samples may pose a risk for human health. We consider that with obeying the rules of good hygiene practices (GHP), good manufacturing practices (GMP) and HACCP can minimize the contamination with Listeria spp.
\end{abstract}

Keywords: broiler wing meat; L. monocytogenes; Listeria spp.; hygienic quality.

Practical Application: Taking hygienic measures in broiler flocks at farm level may minimize the contamination with Listeria.

\section{Introduction}

Poultry meat (broiler wing meat), as a protein resource, is a significant element of barbecue culture in Turkey. A significant amount of poultry meat by means of wing meat is consumed by barbecuing especially in summer, spring and autumn months. Poultry meat also has an important place in the kitchen because of its quick preparation and easy service in addition to its cheaper price in comparison with red meat. Poultry meat comes into prominence as a solution for the shortage of red meat beacause of the rapid population growth and the problems of bovine breeding in Turkey during the last decade. Investments in the poultry meat sector are increasing day by day related to the lack of red meat production. Consequently small, medium and large scale breeding units and broiler slaughterhouses in the developed areas of Turkey have been established and is still being established. Turkish Poultry Meat Producers and Breeders Association (2013) stated that the production of chicken meat in Turkey was 1.687 thousand tons in 2012 and there are more than 12.000 broiler establishments.

Microbial contaminations which can occur as a result of wrong techniques during poultry slaughtering process, defective cutting practices and insufficient sanitation programmes can pose risk in terms of human health. Regarding microbial contamination of food, researches done for the detection of Listeria monocytogenes in different foods (Çolak et al., 2007; Elmalı et al., 2013; Holko et al., 2002; Kalorey et al., 2005; Kılınç, 2001; Şireli \& Gücükoğlu, 2008) showed that those foods were substantially contaminated with the bacterium which can have clinical courses of meningitis, meningoencephalitis, and septicemia in human body in addition to the characteristics of L. monocytogenes such as invasion in neutrophiles and macrophages (Marquis et al., 1995; Sibelius et al., 1999), high resistance against heat treatment, its vital activity in high salt concentrations, being psychrotroph and multiplying in aerob and anaerob conditions. Listeriolysin-O (LLO), a hemolysin, is one of the important pathogenicity factors of $L$. monocytogenes and $h l y A$ gene is responsible for encoding this pathogenicity factor. Phospholipases and internalins can be counted as other virulence factors of the bacterium (Swaminathan et al., 2007). Newborn babies, pregnant women, people with repressed immune system, infants and elders are in high-risk group for Listeria infections (Erol, 2007).

Broiler wing meat is an essential element of the barbecue culture in Turkey and can pose a risk as a result of insufficient heat treatment or cross contamination between contaminated meat and salad or other foods.

In this study, we aimed i) to isolate Listeria spp. and L. monocytogenes in broiler wing meat samples, ii) to confirm the isolates by PCR, based on prs and hly $A$ gene sequences, iii) to determine the seasonal and monthly distribution of the isolates.

\section{Materials and methods}

\subsection{Sample collection}

Broiler wing meat samples were purchased from different markets in Hatay province and analysed microbiologically on the same day.

${ }^{1}$ Department of Food Hygiene and Technology, Faculty of Veterinary Medicine, Mustafa Kemal University, Antakya, Hatay, Turkey.

${ }^{2}$ Department of Nutrition and Dietetic, Aydin School of Health Sciences, Adnan Menderes University, Aydin, Turkey.

*Corresponding author: yesimcan@mku.edu.tr 
To monitor monthly and seasonal distribution, 10 samples (5 packaged pieces, wrapped in styrofoam plates using strech film and 5 unpackaged pieces) were collected during every month, and analysed in terms of Listeria spp., and L. monocytogenes. A total of 120 pieces of poultry meat samples (60 packaged pieces, wrapped in styrofoam plates using strech film and 60 unpackaged pieces) were used as materials.

Results were evaluated based on monthly (June-July-August; September-October-November; December-January-February; March-April-May), and seasonally (Summer, Autumn, Winter, Spring) to determine the distribution of the isolates in the samples whether they are packaged or unpackaged.

\subsection{Reference strain}

L. monocytogenes ATCC 19111 was used as a positive control in this study.

\subsection{Microbiological analysis}

From each sample, $25 \mathrm{~g}$ was added to $225 \mathrm{~mL}$ of ONE-broth Listeria (Oxoid, Basingstoke, Hampshire, England) and incubated aerobically at $30^{\circ} \mathrm{C}$ for $22-26$ hours. Then, $0.1 \mathrm{~mL}$ of enrichment broth cultures was inoculated on Brilliance Listeria Agar plates (Oxoid) using spread plate method and incubated at $37^{\circ} \mathrm{C}$ for 22-26 h. Green-blue colonies surrounded by zones on the agar plate were evaluated as suspicious Listeria spp., and Listeria monocytogenes (Oxoid, 2012). Gram staining, rhamnose and xylose sugar, and CAMP (Christie Atkins Munch-Petersen) tests were performed on the suspicious colonies (Harrigan, 1998).

\subsection{PCR analysis}

In the study, specific primers were used to detect prs gene for genus identification, and $h l y A$ gene for L. monocytogenes. For Listeria spp. and L. monocytogenes, primer sequences used in the study were 5' -GCTGAAGAGATTGCGAAAGAAG-3' 5' CAAAGAAACCTTGGATTTGCGG-3' (Doijad et al., 2011); PCRGO:5'-GAA TGT AAA CTT CGG CGC AAT CAG-3'; PCRDO:5'-GCC GTC GAT GAT TTG AAC TTC ATC-3' (Bohnert et al., 1992), respectively.

A commercially available kit (Nucleic Acid Extraction Kit, GF-1, Vivantis, Malaysia) was used for DNA extraction. Extraction was done as described in the protocol. The PCR was performed in a total volume of $50 \mu \mathrm{L}$ containing $1 \times$ PCR buffer (Sigma- Aldrich), $1.5 \mathrm{mM} \mathrm{MgCl}_{2}$ (Sigma-Aldrich), $200 \mu \mathrm{M}$ of each deoxynucleotide, $0.50 \mu \mathrm{M}$ of primers, $1 \mathrm{U}$ Taq DNA polymerase (Sigma-Aldrich), and $10 \mu \mathrm{L}$ template DNA.

Amplification phases carried out were initial denaturation at $98^{\circ} \mathrm{C}$ for $30 \mathrm{~s}$, and then 30 cycles of denaturation at $98^{\circ} \mathrm{C}$ for $7 \mathrm{~s}$, annealing at $60^{\circ} \mathrm{C}$ for $20 \mathrm{~s}$, extension at $72{ }^{\circ} \mathrm{C}$ for $20 \mathrm{~s}$, and then the final extension at $72{ }^{\circ} \mathrm{C}$ for $7 \mathrm{~min}$ (Boeco, Hamburg, Germany). Amplification products were detected by agarose gel (1.5\%) electrophoresis performed at $120 \mathrm{~V}$ for $40 \mathrm{~min}$ (Cleaver, CS-300V, England) and visualised under UV transillumination (UVP, Upland, USA).

\subsection{Statistical analysis}

The nonparametric test (Kruskal-Wallis H test) was performed for determining the significance of differences between the results of monthly (June-July-August; September-October-November; December-January-February; March-April-May) and seasonal (Summer, Autumun, Winter, and Spring) distribution of the isolates.

\section{Results and discussion}

This study was carried out in Laboratory of Food Hygiene and Technology and Central Laboratory of Faculty of Veterinary Medicine, Mustafa Kemal University between June 2012 and May 2013. The monthly (June-July-August; September-October-November; December-January-February; March-April-May) and seasonal (Summer, Autumun, Winter, and Spring) distributions of the isolates and the electrophorese image of L. monocytogenes, and Listeria spp. strains are shown in Table 1, Figure 1, and Figure 2, respectively.

Listeria spp. was isolated from 57 (47.5\%) out of 120 samples and $54(94.7 \%)$ of the 57 isolates were identified as L. monocytogenes.

In the present study, L. monocytogenes was isolated at the levels of $60.0 \%$ (9/15), $73.3 \%(11 / 15), 33.3 \%(5 / 15)$ and $13.3 \%$ $(2 / 15)$ from the packaged samples collected in summer, autumn, winter and spring, respectively. L. monocytogenes was detected

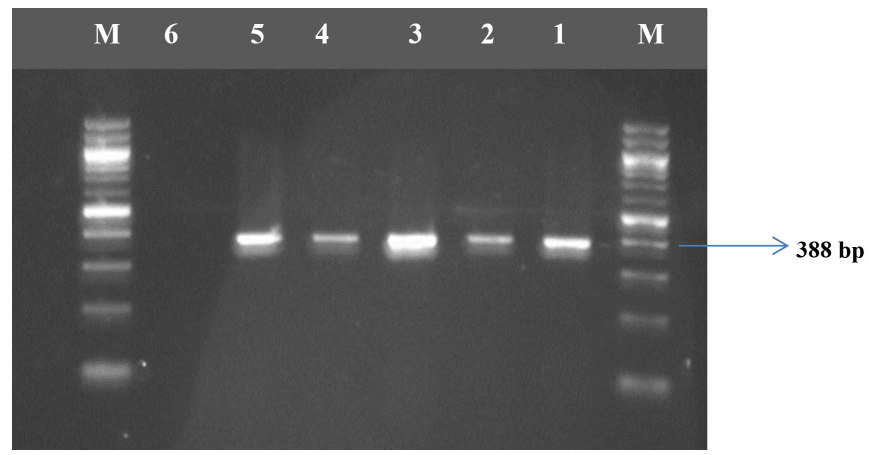

Figure 1. Electrophorese image of $h l y A$ positive L. monocytogenes isolates. M: 100 bp DNA marker (Axygen), line 1: Positive control, lines 2-5: HlyA positive isolates, line 6: Negative control.

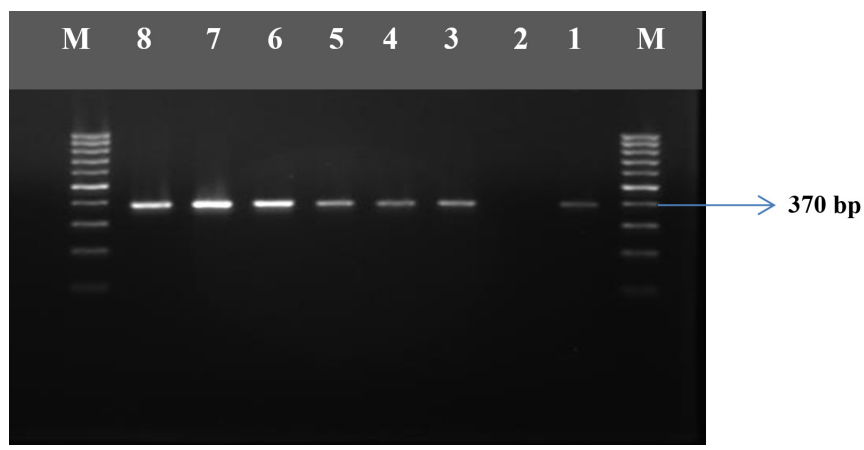

Figure 2. Electrophorese image of prs positive Listeria spp.. isolates. M: 100 bp DNA marker (Axygen), line 1: Positive control, line 2: Negative control, lines 3-8: Prs positive isolates. 
Table 1. The monthly and seasonal distribution of L. monocytogenes and and other Listeria spp.

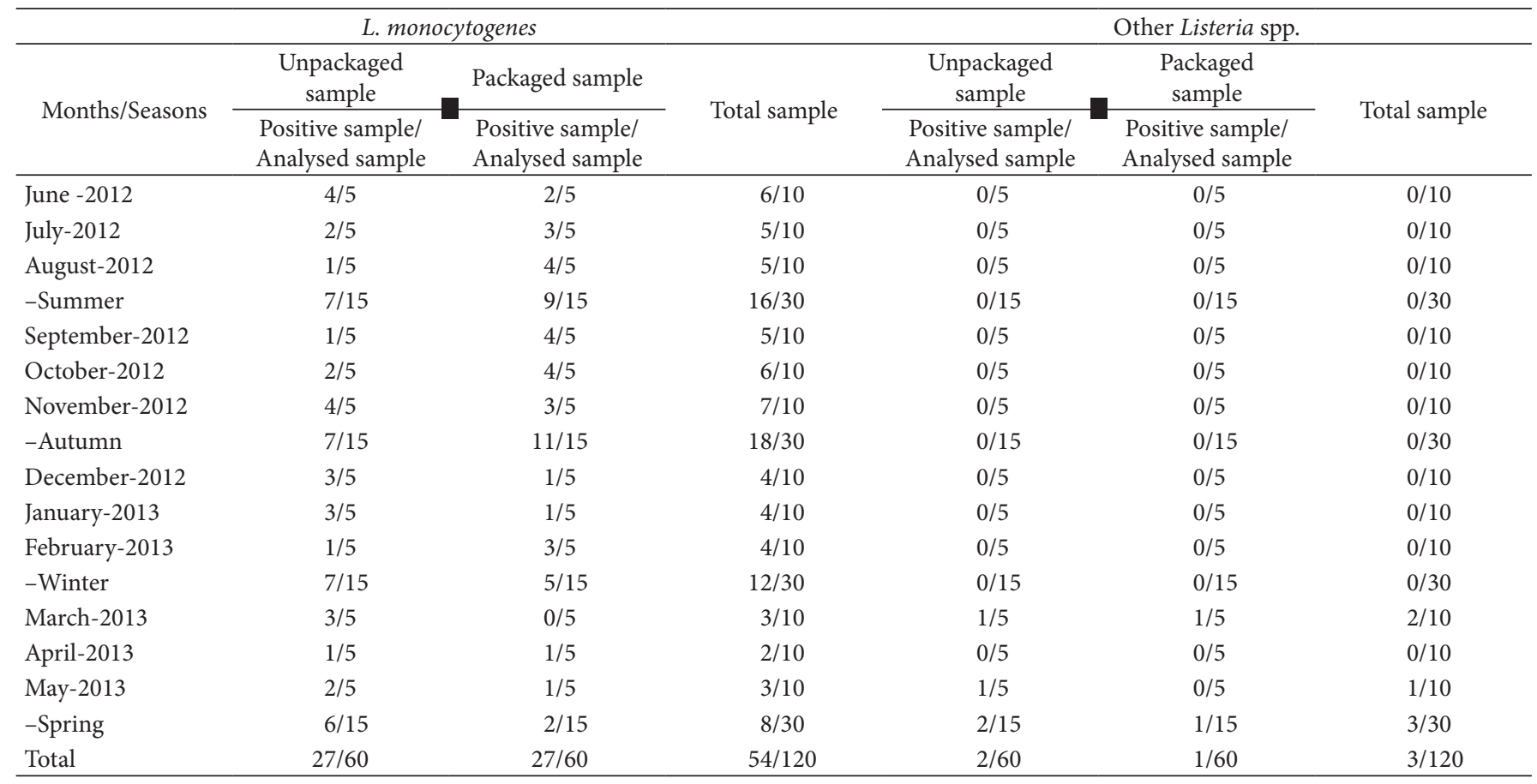

at the level of $46.6 \%$ from the unpackaged samples collected in summer, autumn and winter, while it was $40.0 \%$ (6/15) in spring.

In the evaluation of the isolates according to the seasons; L. monocytogenes was isolated and identified from 16 (53.3\%) out of 30 samples (15 unpackaged +15 packaged) collected during summer; 7 (46.6\%) out of 15 samples offered for sale as unpackaged and $9(60 \%)$ out of 15 samples offered for sale in the straphor plates wrapped in stretch film.

In the samples collected between September 2012-November 2012 (Autumn season), L. monocytogenes was isolated and identified from $18(60 \%)$ out of 30 samples ( 15 unpackaged +15 packaged); 7 (46.6\%) out of 15 unpackaged samples, and 11 (73.3\%) out of 15 packaged samples.

In winter season (between December 2012-January 2013), the numbers of $L$. monocytogenes isolated from 30 samples were found to be 12 (40\%); 7 (46.6\%) out of 15 unpackaged samples, and $5(33.3 \%)$ out of 15 packaged samples.

Finally, L. monocytogenes was isolated and identified from 8 (26.6\%) out of 30 samples between March 2013-May 2013 (Spring season); 6 (40\%) out of 15 unpackaged samples, and 2 (13.3\%) out of 15 packaged samples.

In the comparison of the results in terms of seasons, L. monocytogenes was isolated and identified at the rates of $26.6 \%$, $40 \%, 53.3 \%$, and $60 \%$ in spring, winter, summer, and autumn, respectively. The highest rate was found during the autumn, while the lowest isolation rate was in spring.

Based on the seasonal or monthly prevalences of $L$. monocytogenes determined in this study, the differences between the packaged and unpackaged samples were not statistically significant, while a statistical difference $(\mathrm{p}<0.01)$ was determined in the packaged samples between the seasons, but no significant differences ( $p>0.05)$ were determined between the months in the samples.

Vasilev et al. (2010) stated that $L$. monocytogenes was isolated from 27\% of the broiler carcasses in Israel betweeen 1998-2007. Bilir Ormanci et al. (2008) found 23 (12.7\%) of the analysed 180 turkey meat samples being contaminated with L. monocytogenes. The results of these two studies are proportionately lower than the results gathered in this study. Research period of Vasilev et al. (2010), however, lasted longer than our study period while the research period of Bilir Ormanci et al. (2008) was shorter. These differences in the results may related to research time.

Osaili et al. (2011) stated that Listeria spp. was isolated from 160 pieces of raw broiler samples and 15 (9.4\%) of these were identified as L. monocytogenes. Another researcher Soultos et al. (2003) isolated Listeria spp. from $48 \%$ (38/80) of the broiler meat samples, and 14 (18\%) of these samples were determined as L. monocytogenes whereas Capita et al. (2001) found Listeria spp. in the $95 \%$ of the 100 broiler carcasses, and L. monocytogenes was identified from $15 \%$ of the samples.

Meyer et al. (2012) found Listeria spp. at the level of 6\% from 300 pieces of ready-to-eat broiler meat according to ISO 11290-2;2005 protocol. Considering the results of Osaili et al. (2011) and Soultos et al. (2003) regarding Listeria spp., approximate values to our study were observed and they were very low in terms of L. monocytogenes while the rate of Listeria spp. found by Capita et al. (2001) were very high in comparison with our results. The highly low rates of L. monocytogenes in the studies of Osaili et al. (2011), Soultos et al. (2003), Meyer et al. (2012) and Capita et al. (2001) in comparison with our study may be related to the microbial profile of poultry houses, cleanliness and 
hygienic conditions applied in the poultry slaughters, personal hygenie and low level of cross contamination.

\section{Conclusion}

Listeria is the bacterium that does listeriosis in human. L. monocytogenes causes meningitis and septicemia in humans and also, leads to high rates of death in immunosuppressed individuals. Because of this bacteria can survive for long periods of time in the environment, and can grow at refrigerator temperature, this makes difficult to control foodborne listerial infections.

Our results indicated the high prevalence of Listeria spp. and L. monocytogenes in broiler wing meat samples. The severity and case-fatality of the disease require appropriate preventive measures. Therefore, taking hygienic measures at farm and slaughterhouse level may play an important role in terms of controlling the contamination with Listeria. We consider that with obeying the rules of good hygiene practices (GHP), good manufacturing practices (GMP) and HACCP in the manufacturing process and slaughterhouses can substantially decrease the prevalence of Listeria spp. which can pose a risk for human health.

\section{Acknowledgements}

This study was supported by Mustafa Kemal University, Project code of BAP-1201M0115.

\section{References}

Bilir Ormanci, F. S., Erol, I., Ayaz, N. D., Iseri, O., \& Sariguzel, D. (2008). Immunomagnetic separation and PCR detection of Listeria monocytogenes in turkey meat and antibiotic resistance of the isolates. British Poultry Science, 49(5), 560-565. http://dx.doi. org/10.1080/00071660802298328. PMid:18836902.

Bohnert, M., Dilasser, F., Dalet, C., Mengaud, J., \& Cossart, P. (1992). Use of specific oligonucleotides for direct enumeration of Listeria monocytogenes in food samples by coloni hybridization and rapid detection by PCR. Research in Microbiology, 143(3), 271-280. http:// dx.doi.org/10.1016/0923-2508(92)90019-K.

Capita, R., Calleja, C., Moreno, B., \& Fernandez, M. C. C. (2001). Occurence of Listeria species in retail poultry meat and comparison of cultural /Immunoassay for their detection. International Journal of Food Microbiology, 65(1-2), 75-82. http://dx.doi.org/10.1016/ S0168-1605(00)00497-9.

Çolak, H., Hampikyan, H., Bingöl, B. E., \& Ulusoy, B. (2007). Prevalence of Listeria monocytogenes and Salmonella spp. in Tulum cheese. Food Control, 18(5), 576-579. http://dx.doi.org/10.1016/j. foodcont.2006.02.004.

Doijad, S., Barbuddhe, S. B., Garg, S., Kalekar, S., Rodrigues, J., D'Costa, D., Bhosle, S., \& Chakraborty, T. (2011). Incidence and genetic variability of Listeria species from three milk processing plants. Food Control, 22(12), 1900-1904. http://dx.doi.org/10.1016/j. foodcont.2011.05.001.

Elmal1, M., Oner, S., \& Yaman, H. (2013). Detection of Listeria monocytogenes by using PCR method in refrigerated ready to eat food consumed in Turkey. Medycyna Weterynaryjna, 69(1), 36-39. Retrieved from http://www.researchgate.net/publication/274384000.
Erol, I. (2007). Listeria. In I. Erol (Ed.), Food hygiene and microbiology (pp. 126-134). Ankara, Turkey: Pozitif Matbaacilı.

Harrigan, W. (1998). Laboratory methods in food microbiology (3rd ed.). Waltham, Massachusetts: Academic Press.

Holko, I., Urbanova, J., Kantikova, M., Pastorova, K., \& Kmet, V. (2002). PCR detection of Listeria monocytogenes in milk and milk products and differentation of suspect isolates. Acta Veterinaria Brno, 71(1), 125-131. http://dx.doi.org/10.2754/avb200271010125.

Kalorey, D. R., Barbuddhe, S. B., Kurkure, N. V., \& Gunjal, P. S. (2005). Prevalence of Listeria monocytogenes in poultry meat in Vidharba region of India. In Proceedings of the 17th European Symposium on the Quality of Poultry Meat. Doorwerth, Netherlands.

Kilınç, B. (2001). Su Ürünlerinde Listeria monocytogenes. E.U. Journal of Fisheries \& Aquatic Sciences, 18(3-4), 565-574. Retrieved from http://jfas.ege.edu.tr/

Marquis, H., Doshi, V., \& Portnoy, D. A. (1995). The broad range phospholipase $\mathrm{C}$ and a metalloprotease mediate listeriolysin O-independent escape of Listeria monocytogenes from a primary vacuole in human epithelial cells. Infection and Immunity, 63(11), 4531-4534. PMid:7591098.

Meyer, C., Ahomaa, M. F., Kleta, S., Ellerbroek, L., Thiel, S., \& Mörtlbauer, E. (2012). Occurence of Listeria monocytogenes in ready to eat poultry products available on the German Market. Food Research International, 48(2), 944-947. http://dx.doi.org/10.1016/j. foodres.2012.02.022.

Osaili, T. M., Alaboudi, A. R., \& Nesiar, E. A. (2011). Prevalence of Listeria spp. and antibiotic susceptibility of Listeria monocytogenes isolated from raw chicken and ready to eat chicken product in Jordan. Food Control, 22(3-4), 586-590. http://dx.doi.org/10.1016/j. foodcont.2010.10.008.

Oxoid (2012). Rapid culture method: Listeria precis. Retrieved from http://www.oxoid.com/pdf/uk/27363_Listeria_Precis.pdf

Sibelius, U., Schulz, E. C., Rose, F., Hattar, K., Jacobs, T., Weiss, S., Chakraborty, T., Seeger, W., \& Grimminger, F. (1999). Role of Listeria monocytogenes exotoxins listerolysin and phosphatidylinositol-specific phospholipase $\mathrm{C}$ in activation of human neutrophils. Infection and Immunity, 67(3), 1125-1130. PMid:10024552.

Soultos, N., Koidis, P., \& Madden, R. H. (2003). Presence of Listeria and Salmonella spp. In retail chicken in Northern Ireland. Letters in Applied Microbiology, 37(5), 421-423. http://dx.doi.org/10.1046/j.1472765X.2003.01423.x.

Swaminathan, B., Cabanes, D., Zhang, W., \& Cossart, P. (2007). Listeria monocytogenes. In M. P. Doyle \& L. R. Beuchat (Eds.), Food microbiology: fundamentals and frontiers (chap. 3, pp. 457-491). Washington: ASM Press.

Şireli, U. T., \& Gücükoğlu, A. (2008). Prevalence and antibiotic resistance of Listeria spp. isolated from ready-to-eat foods in Ankara. Turkish Journal of Veterinary and Animal Sciences, 32(2), 131-135.

Turkish Poultry Meat Producers and Breeders Association (2013). Poultry meat summary sector report. Retrieved from http://www. besd-bir.org/en/sector-information

Vasilev, V., Japheth, R., Breuer, R., Andorn, N., Abraham, B. R., Yoni, Y., Valinsky, L., \& Agmon, V. (2010). A survey of Listeria monocytogenes strains, isolated from ready to eat foods in Israel over a period of 10 years, 1998-2007. Food Control, 21(8), 1179-1181. http://dx.doi. org/10.1016/j.foodcont.2010.01.015. 